\title{
The power of survivor advocacy: making car trunks escapable
}

\author{
Elizabeth McLoughlin, Janette Fennell
}

\begin{abstract}
Survivor advocates are powerful workers for injury prevention. Some of the major prevention successes have been due in large part to their efforts. This case history examines the four year campaign to prevent entrapment in car trunks (or boot) through the routine installation of interior trunk releases. It traces how a life altering event began a cluster of activities leading to product redesign and regulation to prevent injury. The following elements were key: data and the lack thereof, identification of possible solutions, newsworthy tragedies and media advocacy, politics and sympathetic lawmakers, an agency with regulatory authority, manufacturers, and trade associations. Survivors can assist the injury field because the personal and the professional complement each other in advocacy. Public health professionals can assist survivor advocates by sharing research, data and organizational skills, and by helping to secure grants. (Injury Prevention 2000;6:167-170)
\end{abstract}

Keywords: legislation; product design; survivors; car trunk (boot)

Survivor advocates have influenced some of the most important injury control advances in the 20 th century. These include the prevention of drunk driving (MADD-Mothers Against Drunk Driving), and firearm deaths and injuries (Handgun Control, Inc in the USA, and the work of families of schoolchildren killed in Dunblane, Scotland). Organizations established by survivor advocates were also central to passage of California's motorcycle helmet law (Californians for Safe Motorcycling), pool fencing ordinances (The Drowning Prevention Foundation), and standards for crib design (The Danny Foundation).

This case history is but one example of survivor advocacy for injury prevention. It examines activities over a four year period which led to the making of interior trunk releases standard equipment in vehicles. From this story, and experiences with other survivor advocates, we draw implications for injury control professionals who want to work with survivor advocates.
The life altering event

Janette Fennell's story is chilling. In October 1995 in San Francisco, California, USA, armed robbers rolled under the descending garage door as she, her husband, and infant returned home near midnight. The Fennells were ordered at gunpoint to get into the car trunk without their baby, driven to a remote area, robbed, and abandoned. Trapped inside the pitch black trunk, and frantic about their son, they tore apart the trunk's interior and found a buried release cable. Using it, they freed themselves and drove to a phone to call the police. Their baby, left in his car seat outside their home, was safe in a policeman's arms when they got home.

Ms Fennell had experience in sales and marketing, not injury prevention. She knew, however, that the 1960's problem of children being entrapped and dying in discarded refrigerators had been addressed by regulation and product redesign. ${ }^{1}$ She felt strongly that any manufacturer who produced a product that could trap people inside it was obliged to provide a means of escape.

Her goal was to make car trunks escapable. To reach this goal, she founded the organization TRUNC (Trunk Releases Urgently Needed Coalition; web site: http:// www.netkitchen.com/trunc) in 1996 and created its web site in mid-1997. Largely due to her efforts, the problem of trunk entrapment went from a denied problem through the early 1990s to a 1999 federal proposed rulemaking. Some US car makers are making interior trunk releases standard in their year 2000 models.

\section{Problem definition and data}

Problem definition is essential to solution. Trunk entrapment results innocently from children playing and adults working inside trunks. More commonly, it results from criminal behavior: carjackings, kidnappings, assaults, robbery, or murder. Data on entrapment are very hard to find. Criminal justice records include crimes involving trunk entrapment, but this can be discovered only by reading the noncomputerized narrative. The police recorded the Fennell entrapment as a robbery.

In the United States, the National Highway Traffic Safety Administration (NHTSA)'s data systems contain information only on traffic 


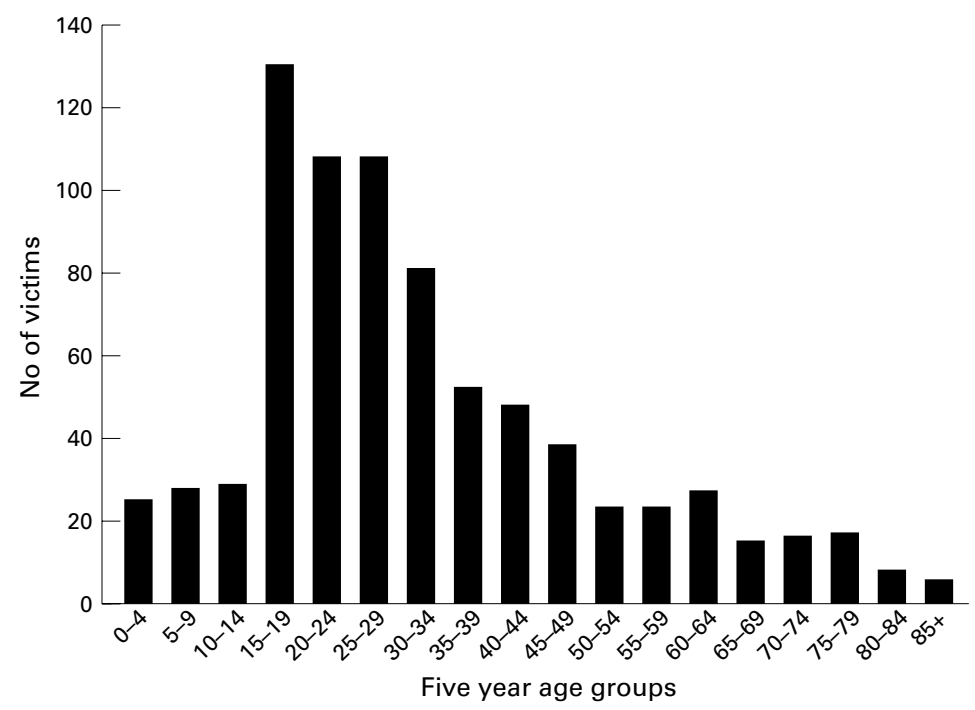

Figure 1 Distribution by age group of 782 entrapment victims with known age (1976-2000). method of non-conventional data collection, grounded in the expanding resources of the internet, could serve as a model for advocates and public health professionals facing absence of data.

\section{Selecting an appropriate intervention}

William Haddon guided the injury field toward considering host, agent, and environmental factors in designing prevention strategies. Environmental solutions are most effective, although not all problems can be solved through passive protection. ${ }^{2}$

For trunk entrapment, a simple, inexpensive, environmental "fix" made sense. In most contemporary cars, there is a cable through the trunk that connects the passenger compartment release lever with the trunk's release mechanism. A visible device to reach and pull on that cable might work. Indeed, car manufacturers had examined this solution and estimated the cost of an interior trunk release mechanism to be between 20 cents and $\$ 5$ per vehicle. ${ }^{3}$

However, NHTSA and the car makers did not act. They argued that, since criminal behavior was the most common cause of trunk entrapment, if trunks were escapable, criminals would disable the mechanism or maim victims to prevent escape. ${ }^{4}$ This argument for inaction was countered by the 1999 Expert Panel on Trunk Entrapment. Its discussion with criminologists confirmed that one could not predict the impact of internal releases on criminal behavior. The panel determined that internal trunk releases were "an essential element in preventing trunk entrapment”. ${ }^{6}$

\section{Newsworthy tragedies and media advocacy}

In the history of injury and violence prevention, it is not unusual for news headlines to create a readiness for policy change. Extensive local media coverage of the Fennell kidnapping and trunk entrapment attracted the attention of national media. The Fennells agreed to collaborate, as long as the focus was on prevention. They appeared on a nationally syndicated talk show in January 1997, urging viewers to support interior trunk releases as standard features in all vehicles. In December 1997, a prime time investigatory program ran a feature segment about trunk entrapment and releases.

Then, in July/August of 1998, 11 children under 7 years of age died of hyperthermia after being trapped in trunks in three separate incidents in relatively remote areas of New Mexico, Pennsylvania, and Utah. Ms Fennell led a journalist for a national newspaper to link the three stories. This linkage reframed the story from isolated "freak accidents" to a significant health and safety problem. The Centers for Disease Control and Prevention reported on childhood trunk entrapments in December 1998.

Trunk entrapment became prime time news. Because Ms Fennell had the only database and was well informed, she was able to influence coverage of these unwelcome but newsworthy of actual trunk entrapments in the US this database represents. It is a "minimum set" of known cases during the past 25 years. This 
tragedies to argue for trunk releases. These arguments entered the media through various popular print and electronic channels and thus generated additional grassroots support.

\section{Politics and sympathetic lawmakers}

Injury control must often be implemented through the political process. Thus, advocates must find at least one policymaker to carry their legislative solution. Ms Fennell's path started with a nurse in a Wisconsin hospital, who knew about a children's organization that might be interested in TRUNC's work. This organization led to a police chief investigating abductions, who introduced her to his friend Bart Stupak, a former state trooper and Congressman from Michigan.

Representative Stupak was convinced that cars should have inside trunk releases, and introduced a bill to that effect. The Congress was unwilling to regulate trunk releases. However, in June 1998, as part of its omnibus transportation bill, Congress included Stupak's amendment requiring NHTSA to conduct a study of trunk entrapment, to be completed by December $1999 .^{8}$

This action preceded the highly publicized childhood fatal entrapments in August of 1998. Nevertheless, it served as a concrete action that politicians could support in response to public outcry about the children's deaths. California's Senator Feinstein wrote to the Secretary of Transportation, asking him to expedite this study. In fact, the study's recommendations were issued in June 1999.

\section{Regulation: the National Highway Traffic} Safety Administration

In 1984, NHTSA denied a petition for rulemaking from a Missouri man to require an interior trunk release lever, citing absence of data about the problem or justification for the solution. ${ }^{4}$ Here is a dilemma. A regulatory agency does not collect data about a particular problem, then claims that the problem does not exist because there are no data.

In June 1998, NHTSA received a congressional mandate to study trunk releases. Then in July and August, 11 children died while trapped in trunks. In November 1998, NHTSA asked the National SAFE KIDS Campaign, a non-profit agency working to prevent unintentional injuries to children, to help implement the trunk entrapment study. They formed the Expert Panel on Trunk Entrapment, which included experts from psychiatry, law enforcement, health and medicine, safety advocacy (including Ms Fennell), and the automotive and toy industries.

The panel recommended that NHTSA should issue a standard requiring vehicles to be equipped with interior trunk release mechanisms. ${ }^{5}$ In December, 1999, NHTSA issued for public comment a proposed rulemaking to mandate that release mechanisms be installed by 1 January $2001,{ }^{9}$ leaving the mechanism's design to the auto makers.
Manufacturers and trade associations Almost naively, the Fennells thought that by bringing the problem of trunk entrapment to the attention of car makers, the latter would fix it. Therefore, early in 1997, they contacted all car makers selling cars in the US. These letters were virtually ignored, despite, in the case of General Motors, an incident where the son of a former chief executive was kidnapped in 1975 and held for ransom in a car trunk for two days. A second Fennell letter in November 1997 drew a similar response. An industry employee informed the Fennells that trunk entrapment was discussed during a monthly conference call among all international auto makers, and they decided to do nothing about it.

The American Automobile Manufacturers Association (AAMA) did write a letter to the Fennells in January 1998, after a prime time TV investigatory program indicated that auto makers were unresponsive. Ironically, the person who signed the trade association's letter dismissing the issue was the same person who signed the NHTSA 1984 denial of rulemaking published in the Federal Register. In 1984, he was NHTSA's associate administrator for rulemaking; in 1998, he was the Director of Regulatory Affairs for the AAMA.

After the deaths of the 11 children in the summer of 1998, and in the light of public outcry, auto manufacturers and their trade associations could no longer deny the problem or appear indifferent to finding a solution. As of September 1999, the Ford Motor Co has installed a glow-in-the-dark release handle inside the trunk as a standard feature on most of its 2000 model cars. It includes a warning about trunk entrapment in the "hang tag" that accompanies new cars. Other auto manufacturers are in various stages of readiness to meet the proposed deadline. General Motors and DaimlerChrysler AG currently offer retrofit kits for $\$ 50$ for use in installing trunk releases in most cars built after 1990 .

\section{The "watchdog" function}

Although injury professionals may be diverted to other problem areas, survivor advocates will not. As Ms Fennell told General Motors in 1997, "we're not going away". A legislative or regulatory victory does not end their vigilance. Advocates must monitor the implementation of solutions, in this case, the availability and usefulness of retrofit kits in all sections of the country. They could also monitor media portrayals of the issue. In January 2000, Ms Fennell had a regional Ford car commercial withdrawn from the air. It trivialized trunk entrapment by featuring a youth who gleefully shuts himself in a car trunk to sneak into a drive-in movie.

\section{Implications of survivor advocacy for the} injury field

As with all case studies, this one has some nongeneralizable features. It is specific to the US's regulatory and media environment. Ms Fennell had resources and skills that other survivor 
advocates might not have. The trunk entrapment problem had a concrete solution, although the car makers are still designing appropriate devices. But there are many aspects of the story that are relevant for the injury control field.

It raises a question about priorities, strategies, and diversification of effort. Should the injury field concentrate on the major killers and disablers, or should it devote time, attention, and dollars to a wide variety of injury problems? We argue that when a survivor advocate wants to prevent others from suffering a particular tragedy, we should pay attention. In this case, it was argued that trunk entrapment was too small a problem to merit regulatory attention. Sometimes, as here, problems are considered small only because data are lacking. Data collection, maintenance, and interpretation are public health and injury control responsibilities. With the powers of computerized databases, data linkage efforts, the internet and non-traditional sources of data, professionals are positioned to help survivor advocates clarify and define a problem.

But suppose the problem is, indeed, rare. Do we dismiss a survivor advocate's appeal for help? Now other issues must be explored. Is there a cost effective solution which, if implemented, would reduce the problem? If there is, then we should support the advocate to achieve the solution. Because nothing succeeds like success, our field can only benefit from concrete examples of successful injury control interventions. An accumulation of small but meaningful successes will go far to dispel the still prevalent opinion that "accidents will happen" and the corollary, that not much can be done about them.

Survivors bring a passion to prevention. Injuries and trauma affect individuals and families in profound, life altering ways. It is not unusual for survivors to turn to prevention as one way of channeling grief. Survivors' work is personal and passionate. These are the qualities that make their message attractive to the media, persuasive to some policymakers, puzzling to many professionals, and aggravating to their opponents. Professionals working with survivor advocates (particularly those grieving a death) might devote considerable time and energy dealing with personal and emotional issues.

Does this emotional involvement in prevention bring healing? A review of the literature revealed little about the healing properties of injury prevention advocacy. However, two articles argued that "going public" and becoming politically active improved healing for survivors of incest and sexual abuse, ${ }^{10}$ and for victims of war crimes. ${ }^{11}$

The partnership between survivors and professionals creates a powerful alliance of authenticity with expertise. Injury professionals have been attacked and dismissed as "do-gooders" and "safety fascists". It is much more difficult for opponents to brush aside survivor advocates. They put a face on the statistics; their stories are compelling and real. They have a persistency that will outlast opponents whose attention can be diverted to other issues. Injury professionals have scientific, programmatic, and data expertise to offer survivor advocates. Coupled testimony at hearings can be persuasive, with the survivor advocate arguing policy change from the personal perspective, and the professional arguing policy change from the scientific perspective.

Some survivors initiate contact with public health professionals; indeed, the better known and more effective survivor advocates are initiators. Injury prevention professionals need to publicize their agendas, strategies, and success stories more broadly. This information will allow initiating survivors to establish contact, and will prevent them from wasting time and energy on ineffective solutions.

Recruiting, or more appropriately, inviting non-initiating survivors to become active in prevention requires great sensitivity. Only a few will become active. Depending upon the circumstances of the incident, survivors deal with guilt, remorse, or anger as well as with grief. They commonly need at least six months to return to some normalcy. The best invitations make it easy for survivors to decline them, and are very specific as to what actions are requested.

Funding the work of survivor advocates is very difficult. Lobbying and advocacy are expensive. Time is taken from family or paying jobs, and money is needed for travel, telephone, postage, and office supplies. Many draw down personal savings, often to the detriment of their families' financial stability. Injury professionals can help survivors fund their work by sharing grant getting skills and personal contacts which might result in pro bono work or other funding.

John Stuart Mill wrote: "One person with a belief is equal to the force of 99 who have only an interest". Survivor advocates bring to public health and the injury field a passionate belief in prevention.

1 US Consumer Product Safety Commission. CPSC warns about suffocation and death of children in old refrigerators. Safety Alert CPSC document \#5072. Washington, DC: CPSC, 1956.

2 Haddon W, Baker SP. Injury control. In: Clark D, MacMahon B, eds. Preventive and community medicine. Boston, MA: Little, Brown, 1981.

3 Max Gates of the auto manufacturers association, quoted in USA Today, 13 August 1998.

4 Department of Transportation, National Highway Traffic Safety Administration. Federal register. Washington, DC: DOT, NHTSA, 49(233), 3 December 1984 (49 CFR Part 571.)

5 General Motors Corporation. Letter to Ms J Fennell, March 1997.

6 Expert Panel on Trunk Entrapment recommendations. Trunk Entrapment Panel participants. June 1999

7 Centers for Disease Control and Prevention. Fatal car trunk entrapment involving children-United States, 1987-1998. MMWR Morb Mortal Wkly Rep 1998;47(47):1019-22.

8 National Highway Traffic Safety Administration. Transportation Equity Act for the 21 st Century (TEA-21) public law 105-178 enacted 9 June 1998.Section 7106(e).

9 Department of Transportation, National Highway Traffic Safety Administation. Docket management system. WashSafety Administation. Docket management
ington, DC. Docket No NHTSA-99-5063.

10 Oppenheimer J. Politicizing survivors of incest and sexual Oppenheimer J. Politicizing survivors of incest and sexual
abuse: another facet of healing. Women $\mathbb{E}$ Therapy 1998;21: $79-87$

11 Mladjenovic L. Beyond war hierarchies: Belgrade feminists' experience working with female survivors of war. Women $\mathcal{E}$ Therapy 1999;22:83-9. 